\title{
Call for Book Proposals: International Series on Consumer Science
}

\author{
Jing Jian Xiao
}

(C) Springer Science+Business Media, LLC 2008

This book series will be published by Springer in the next several years. Three unique features of the series are reflected from its title. (1) "Consumer" in the title refers to individuals and families. The purpose of the series is to address current and important economic issues faced by consumers to help improve their well-being. (2) We use "Consumer Science" in the title instead of consumer economics, consumer psychology, consumer sociology, consumer politics, etc., because we would like to promote multidisciplinary and interdisciplinary approaches to addressing important consumer economic issues. (3) We use "International" in the title because we envision the series will serve international audiences in a long term. Currently, we have a dozen books underway addressing consumer economic issues from a variety of perspectives and contributed by scholars from diverse academic fields.

If you are interested in contributing a book to this series, please send a tentative title and brief description of the book, intended audiences, and a short bio of the author (or editor if you decide to publish an edited volume) to the series editor, Jing Jian Xiao at: jfei.editor@gmail.com.

J. J. Xiao $(\square)$

Transition Center, University of Rhode Island, Kingston,

RI 02881, USA

e-mail: jfei.editor@gmail.com 